http://dx.doi.org/10.11646/phytotaxa.141.1.1

\title{
Morphological characterization of seeds in Portulacaceae
}

\author{
GILBERTO OCAMPO ${ }^{1,2}$ \\ ${ }^{I}$ Rancho Santa Ana Botanic Garden and Claremont Graduate University, 1500 North College Avenue, Claremont, CA 94706, USA. \\ ${ }^{2}$ Current address: California Academy of Sciences, Department of Botany, 55 Music Concourse Drive, Golden Gate Park, San \\ Francisco, CA 94118, USA. E-mail: gocampo@calacademy.org
}

\begin{abstract}
Portulacaceae is a monogeneric family with around 100 species distributed around the world. Seed morphology is diverse in this group, and its variation has been used for taxonomic and identification purposes. However, documentation of seed morphology has focused on a few species complexes or has been limited to specific countries and geographic areas. Moreover, the terminology employed in different investigations is heterogeneous, thus complicating analyses of seed morphological diversity in Portulacaceae. In this study, the seed morphology of 58 samples representing 49 species, 9 subspecies, and 2 cultivars of Portulaca was documented with the use of scanning electron microscopy (SEM). Based on the examination of the resulting images, a set of morphological features for describing the general shape of the seeds and their individual cell features is proposed; in addition, morphological descriptions for all taxa included in this study are provided. The results indicate that the shape of the seeds was constant within species, contrary to the characters that describe individual cell features, which showed important variation even within the same seed sample. In particular, the outline of the cells and the curvature of the anticlinal cell walls (ACW) were very variable, so a combination of character states was needed to describe the overall diversity of a sample. Conversely, the relief of the periclinal cell walls (PCW) was relatively constant throughout the seeds of the same species, but the relief of the cells of the lateral and peripheral faces was dissimilar in a number of taxa. In addition, other studies provide evidence that the relief of the PCW may vary in widely distributed species. Increased taxon sampling and multiple samples of species with wide geographical ranges will facilitate the study of patterns of variation, and may provide insights into the role of environmental variables on seed diversity of Portulacaceae.
\end{abstract}

Key words: Caryophyllales, Portulaca, scanning electron microscopy

\section{Introduction}

Portulaca L. is the only genus in the recently recircumscribed Portulacaceae (Nyffeler \& Eggli 2010). The family has ca. 100 species that are distributed worldwide mainly in tropical and subtropical regions (Legrand 1953). Plants of this family are herbs, annuals or perennials; the flowers are solitary or are arranged in cymose inflorescences (frequently compact and resembling capitula), and the fruit is a dehiscent circumscissile capsule that produces subreniform to suborbicular seeds (Figs. 1A-B). A recent molecular phylogenetic study showed that the family is monophyletic with high support and is composed of two main clades (Ocampo \& Columbus 2012). One of them has opposite-leaved representatives restricted to the Old World (OL clade), except the pantropical weed P. quadrifida L., and its species form two subclades whose distributions are restricted to Africa and Asia (African-Asian clade) and to Australia (Australian clade). The second main clade has species with alternate or subopposite leaf arrangement and are distributed around the world (AL clade). Three monophyletic groups are recognized within the AL clade, and include widely known species like $P$. pilosa L. (Pilosa clade), P. oleracea L. (Oleracea clade) and the cultivar of P. umbraticola Kunth (Umbraticola clade). 
Herbarium for access to herbarium collections; James André, J. Travis Columbus, Stephen Dreher, Amanda Ingram, Tasha LaDoux, Oscar Morales, Sarah Siedschlag, and Valerie Sosa for their companionship and assistance during fieldwork; Wendy Applequist, J. Travis Columbus, and Lucinda McDade for reviewing earlier versions of this manuscript. This study was supported by Rancho Santa Ana Botanic Garden, the Cactus and Succulent Society of America, Claremont Graduate University, the Claremont University Club, and The Community Foundation serving the Riverside and San Bernardino Counties. Financial support to the author was provided by Rancho Santa Ana Botanic Garden, The Fletcher Jones Foundation, Comisión Nacional de Ciencia y Tecnología (Mexico), Fundación Prywer (Mexico), and the Instituto de Ecología, A.C. (Mexico).

\section{References}

Barthlott, W. (1981) Epidermal seed surface characters of plants: Systematic applicability and some evolutionary aspects. Nordic Journal of Botany 1: 345-355. http://dx.doi.org/10.1111/j.1756-1051.1981.tb00704.x

Barthlott, W. \& Hunt, D. (2000) Seed diversity in the Cactaceae, subfamily Cactoideae (Succulent Plant Research, vol. 5). David Hunt, Sherborne, $173 \mathrm{pp}$.

Behnke, H.D. \& Barthlott, W. (1983) New evidence from the ultrastructural and micromorphological fields in angiosperm classification. Nordic Journal of Botany 3: 43-66. http://dx.doi.org/10.1111/j.1756-1051.1983.tb01444.x

Celep, F., Koyuncu, M., Fritsch, R.M., Kahraman, A. \& Doğan, M. (2012) Taxonomic importance of seed morphology in Allium (Amaryllidaceae). Systematic Botany 37: 893-912. http://dx.doi.org/10.1600/036364412x656563

Chance, G.D. \& Bacon J.D. (1984) Systematic implications of seed coat morphology in Nama (Hydrophyllaceae). American Journal of Botany 71: 829-842. http://dx.doi.org/10.2307/2443474

Chuang, T.I. \& Heckard, L.R. (1983) Systematic significance of seed-surface features in Orthocarpus (ScrophulariaceaeSubtribe Castillejinae). American Journal of Botany 70: 877-890. http://dx.doi.org/10.2307/2418868

Danin, A. \& Anderson, L.C. (1986) Distribution of Portulaca oleracea L. (Portulacaceae) subspecies in Florida. Sida 11: $318-24$.

Danin, A. \& Reyes-Betancort, J.A. (2006) The status of Portulaca oleracea L. in Tenerife, the Canary Islands. Lagascalia 26: 71-81.

Danin, A. \& Bagella, S. (2012) A new cultivar microspecies of the Portulaca oleracea aggregate from the E Mediterranean. Willdenowia 42: 63-65. http://dx.doi.org/10.3372/wi42.42106

Danin, A. \& Raus, T. (2012) A key to 19 microspecies of the Portulaca oleracea aggregate. In: Timonin, A.K. (ed.) Caryophyllales: New insights into phylogeny, systematics, and morphological evolution of the order, Proceedings of the Symposium held on $24^{\text {th }}-27^{\text {th }}$ September 2012. Lomonosov State University, Moscow, pp. 70-83.

Danin, A., Baker, I. \& Baker, H.G. (1978) Cytogeography and taxonomy of the Portulaca oleracea L. polyploid complex. Israel Journal of Botany 27: 177-211.

Danin, A., Domina, G. \& Raimondo F.M. (2008) Microspecies of the Portulaca oleracea aggregate found on major Mediterranean islands (Sicily, Cyprus, Crete, Rhodes). Flora Mediterranea 18: 89-107.

Davitashvili, N. \& Karrer, G. (2010) Taxonomic importance of seed morphology in Gentiana (Gentianaceae). Botanical Journal of the Linnean Society 162: 101-115. http://dx.doi.org/10.1111/j.1095-8339.2009.01020.x

Dequan, L. \& Gilbert, M.G. (2003) Portulaca. In: Wu, Z. \& Raven, P.H. (eds.), Flora of China, vol. 5. Science Press, Beijing and Missouri Botanical Garden Press, St. Louis, Missouri, pp. 442-443. http://dx.doi.org/10.1663/0013-0001(2007)61[101b:focvp]2.0.co;2

El-Bakatoushi, R., Alframawy, A.M., Samer, M., El-Sadek, L. \& Botros, W. (2013) Evolution of the Portulaca oleracea L. aggregate in Egypt on molecular and phenotypic levels revealed by morphology, inter-simple sequence repeat (ISSR) and 18S rDNA gene sequence markers. Flora 208: 464-477.

http://dx.doi.org/10.1016/j.flora.2013.07.008

Engelmann, G. (1850) Portulacaceae. Boston Journal of Natural History 6: 153-155.

Euro+Med PlantBase (2006) Information resource for Euro-Mediterranean plant diversity. Available from: http:// 
www.emplantbase.org/home.html (accessed: 12 June 2013).

Geesink, R. (1969) An account of the genus Portulaca in Indo-Australia and the Pacific. Blumea 17: $275-301$.

Gereau, R.E. (2001) Portulacaceae. In: Stevens, W.D., Ulloa, C., Pool, A. \& Montiel, O.M. (eds.) Flora de Nicaragua. Monographs in Systematic Botany from the Missouri Botanical Garden, vol. 85, Missouri Botanical Garden Press, St. Louis, Missouri, pp. 2180-2183. http://dx.doi.org/10.2307/4110958

Gilbert, M.G. \& Phillips, S.M. (2000) A review of the opposite-leaved species of Portulaca in Africa and Arabia. Kew Bulletin 55: 769-802. http://dx.doi.org/10.2307/4113627

Legrand, D. (1953) Desmembración del género Portulaca. Comunicaciones Botánicas del Museo de Historia Natural de Montevideo 3: 1-13.

Legrand, D. (1958) Desmembración del género Portulaca II, adiciones y correcciones. Comunicaciones Botánicas del Museo de Historia Natural de Montevideo 3: 1-17.

Legrand, D. (1962) Las especies americanas de Portulaca. Anales del Museo de Historia Natural de Montevideo, $2^{a}$ serie 7: $1-147$.

Macbride, J.F. (1937) Portulacaceae. Field Museum of Natural History, Botanical series 13: 562-573.

Matthews, J.F. \& Levins, P.A. (1985a) The genus Portulaca in the southeastern United States. Castanea 50: $96-104$.

Matthews, J.F. \& Levins, P.A. (1985b) Portulaca pilosa L., P. mundula I.M. Johnst. and P. parvula Gray in the southwest. Sida. 11: 45-61.

Matthews, J.F. \& Levins, P.A. (1986) The systematic significance of seed morphology in Portulaca (Portulacaceae ) under scanning electron microscopy. Systematic Botany 11: 302-308.

Matthews, J.F., Ketron, D.W. \& Zane, S.F. (1992) Portulaca umbraticola Kunth (Portulacaceae) in the United States. Castanea 57: 202-208.

Matthews, J.F., Ketron, D.W. \& Zane, S.F. (1993) The biology and taxonomy of the Portulaca oleracea L. (Portulacaceae) complex in North America. Rhodora 95: 166-183.

Matthews, J.F., Ketron, D.W. \& Zane, S.F. (1994) The seed surface morphology and cytology of six species of Portulaca (Portulacaceae). Castanea 59: 331-337.

Mueller, F. (1859) Portulacaceae. In: Mueller, F. (ed) Fragmenta Phytographiae Australiae I. Victorian Government, Melbourne, pp. 169-177.

Nyffeler, R. \& Eggli, U. (2010) Disintegrating Portulacaceae: A new familial classification of the suborder Portulacineae (Caryophyllales) based on molecular and morphological data. Taxon 59: 227-240.

Ocampo, G. (2012) Portulacaceae. In: Baldwin, B.G. et al. (eds.) The Jepson Manual: Vascular Plants of California, Second Edition. University of California Press, Berkeley, California, pp. 1126-1128. http://dx.doi.org/10.3120/0024-9637-58.4.273

Ocampo, G. \& Columbus, J.T. (2012) Molecular phylogenetics, historical biogeography, and chromosome number evolution of Portulaca (Portulacaceae). Molecular Phylogenetics and Evolution 63: 97-112. http://dx.doi.org/10.1016/j.ympev.2011.12.017

Phillips, S.M. (2000) Notes on Portulaca L. (Portulacaceae) in Tropical East Africa. Kew Bulletin 55: 687-698. http://dx.doi.org/10.2307/4118786

Phillips, S.M. (2002) Portulacaceae. In: Beentje, H.J. (ed.) Flora of Tropical East Africa. A.A. Balkema, Rotterdam, pp. $1-40$.

Poellnitz, K. (1934) Versuch eine Monographie der Gattung Portulaca L. Feddes Repertorium Novarum Regni Vegetabilis 37: 240-320. http://dx.doi.org/10.1002/fedr.19340371403

Prabhakar, M., Leelavathi, P. \& Kumar, B.K.V. (1990) SEM studies on seeds of Indian Portulacaceae and their taxonomic significance. Asian Journal of Plant Sciences 2: 9-14.

Rasband, W.S. (1997) ImageJ [computer program] U. S. National Institutes of Health, Bethesda, Maryland. Available from http://rsb.info.nih.gov/ij/ (accessed: 20 January 2013).

Ricceri, C. \& Arrigoni, P.V. (2000) L'aggregato di Portulaca oleracea L. (Portulacaceae) in Italia. Parlatorea 4: 91-97.

Whiffin, T. \& Tomb, A.S. (1972) The systematic significance of seed morphology in the neotropical capsular-fruited Melastomataceae. American Journal of Botany 59: 411-422.

http://dx.doi.org/10.2307/2441552 